\title{
Review
}

\section{Wet air oxidation for the decolorization of dye wastewater: An overview of the last two decades}

\author{
Jie Fu a, George Z. Kyzas b,c,* \\ a Environmental Engineering Program, Department of Civil Engineering, Auburn University, Auburn, AL 36849, USA \\ b Department of Petroleum and Natural Gas Technology, Technological Educational Institute of Kavala, Kavala 65404, Greece \\ ' Division of Chemical Technology, Department of Chemistry, Aristotle University of Thessaloniki, Thessaloniki 54124, Greece
}

\section{A R T I C L E I N F O}

\section{Article history:}

Received 21 August 2013

Accepted 17 September 2013

Published 20 January 2014

\section{Keywords:}

Wet air oxidation

Dye wastewater

Decolorization

Sustainability

\begin{abstract}
A B S T R A C T
Wet air oxidation (WAO), a liquid phase reaction between organic materials in water and oxygen, is one of the most economical and technologically viable advanced oxidation processes for wastewater treatment, particularly toxic and high organic content wastewater. WAO is the liquid phase oxidation of organics or oxidizable inorganic components at elevated temperatures $\left(125-320^{\circ} \mathrm{C}\right)$ and pressures (0.5-20 MPa) using gaseous oxygen (or air) as oxidant. In the past two decades, the WAO process was widely studied and applied in the treatment of dye wastewater. Compared to conventional WAO, catalytic WAO processes have higher efficiency and use moderate reaction conditions. The catalysts included homogenous and heterogeneous types. The key points that need to be solved are recycling of homogenous catalysts and better stability of heterogeneous catalysts. In the present review, the technological processes are first introduced, then some research history and hotspots of WAO research are presented, and finally, its application in the treatment of dye wastewater in the past two decades is summarized to reveal the impressive changes in modes, trends, and conditions used. The application includes model pollutant studies and wastewater tests.
\end{abstract}

(C) 2014, Dalian Institute of Chemical Physics, Chinese Academy of Sciences. Published by Elsevier B.V. All rights reserved.

\section{Introduction}

Dye wastewater from the printing and dyeing industry is a major source of environmental contamination. Dyestuff, slurries, dyeing aids, acids and alkalis, and fibers and inorganic compounds are present in dye wastewater [1]. Generally, dye wastewater is characterized by a strong color, high $\mathrm{pH}$, high chemical oxygen demand (COD), and low biodegradability [2]. Such wastewater is difficult to treat, especially with color removal, using conventional wastewater processes [3].

In a brief search in Scopus, many hits were obtained for the term "dye oxidation" (Fig. 1). The major peak for works on the wet air oxidation (WAO) process was in the 21st century. The present review first introduces the technology and process, and the research history and research hotspots of WAO. Its application in dye wastewater treatment is then described in detail. Major conclusions were obtained from the different procedures during the past decades, which strongly influenced the new trends and economic aspects of each time period. All these confirmed the sustainability of this process.

Recently, advanced oxidation processes (AOPs) have received attention as effective pretreatment processes for less biodegradable wastewater [4]. AOPs were first proposed by Glaze [5] in 1987. They were defined as near ambient temperature and pressure water treatment processes based on the generation of hydroxyl radicals $(\bullet \mathrm{OH})$ to initiate the oxidative

\footnotetext{
* Corresponding author. Tel/Fax: +30-2310-858607; E-mail: georgekyzas@gmail.com

This work was supported by Technological Educational Institute of Kavala (President: A.Ch. Mitropoulos).

DOI: 10.1016/S1872-2067(12)60724-4 | http://www.sciencedirect.com/science/journal/18722067 | Chin. J. Catal., Vol. 35, No. 1, January 2014
} 


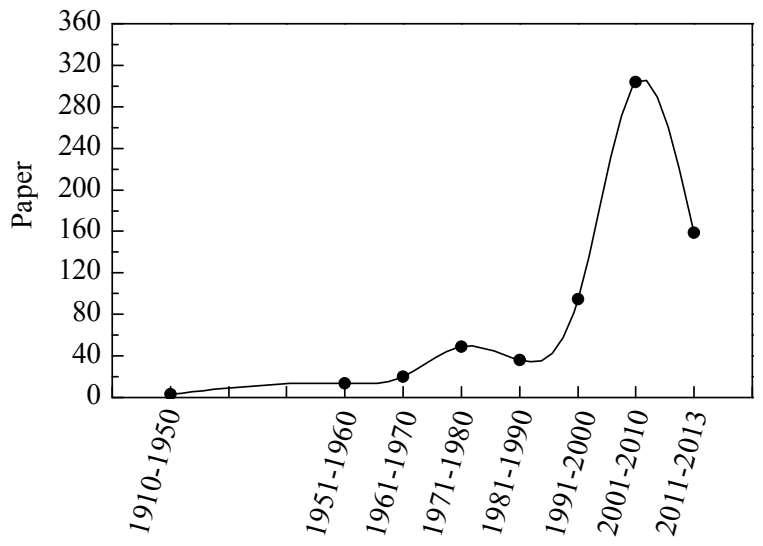

Fig. 1. Works published with the "dye oxidation" keyword (data search in Scopus).

destruction of organics [5]. $\bullet \mathrm{OH}$ is a powerful, non-selective chemical oxidant, which reacts a million to a billion times faster than either ozone $\left(\mathrm{O}_{3}\right)$ or $\mathrm{H}_{2} \mathrm{O}_{2}$ (Table 1) [6].

AOPs can achieve the oxidative destruction of refractory compounds that conventional oxidation cannot. In addition, they have the potential to completely oxidize organic contaminants to $\mathrm{CO}_{2}, \mathrm{H}_{2} \mathrm{O}$, and mineral salts. AOPs can also oxidize inorganic contaminants such as cyanides, sulfides, and nitrites [6]. Their advantages for the treatment of dye wastewater include fast reaction, complete treatment, and being pollution-free and of wide application.

WAO, which was established and developed by Zimmermann [7-10], is one of the most economical and technologically viable AOPs for wastewater treatment, particularly toxic and high organic content wastewater. The application range of each AOP is different and depends on the flow rate and organic content of the effluent [11]. Unlike other AOPs, WAO is suitable for high organic loads at high flow rates. Especially, WAO has great potential for treating effluents containing a high content of organic matter (about 10-100 g/L of COD) and/or toxic con-
Table 1

Relative oxidation power of some oxidizing species with chlorine as the reference species [6].

\begin{tabular}{lc}
\hline Oxidation species & Oxidation power \\
\hline Hydroxyl radical & 2.05 \\
Atomic oxygen & 1.78 \\
Ozone & 1.52 \\
Hydrogen peroxide & 1.31 \\
Permanganate & 1.24 \\
Chlorine & 1.00 \\
\hline
\end{tabular}

taminants, for which a direct biological treatment is not feasible [12]. WAO is not only eco-friendly, but also economical compared to other AOPs that use harmful and expensive oxidants like $\mathrm{O}_{3}$ and $\mathrm{H}_{2} \mathrm{O}_{2}$.

\section{Technology and process}

WAO is the liquid phase oxidation of organics or oxidizable inorganic components at elevated temperatures $\left(125-320^{\circ} \mathrm{C}\right)$ and pressures (0.5-20 MPa) using a gaseous source of oxygen $\left(\mathrm{O}_{2}\right.$ or air $)$ as oxidant. The solubility of $\mathrm{O}_{2}$ in aqueous solutions is greatly enhanced at elevated temperatures and pressures, which provide the strong driving force for oxidation. WAO has been demonstrated to oxidize organic compounds to $\mathrm{CO}_{2}$ and other end products (carbon is oxidized to $\mathrm{CO}_{2}$, nitrogen is converted to $\mathrm{NH}_{3}$ and nitrate ions $\left(\mathrm{NO}_{3}{ }^{-}\right)$, and halogen and sulfur are converted to inorganic forms). WAO is useful for the treatment of hazardous, toxic, and non-biodegradable waste streams. The process becomes self-sustaining when the feed COD is about $20000 \mathrm{mg} / \mathrm{L}$ [13].

Figure 2 shows a typical WAO treatment system. The wastewater is brought into the system using a high pressure pump. Air (or $\mathrm{O}_{2}$ ) is added to the reactor using a compressor. Preheating may be necessary to raise the temperature of the wastewater. The feed temperature is adjusted to let the exothermic heat of reaction raise the mixture temperature to the

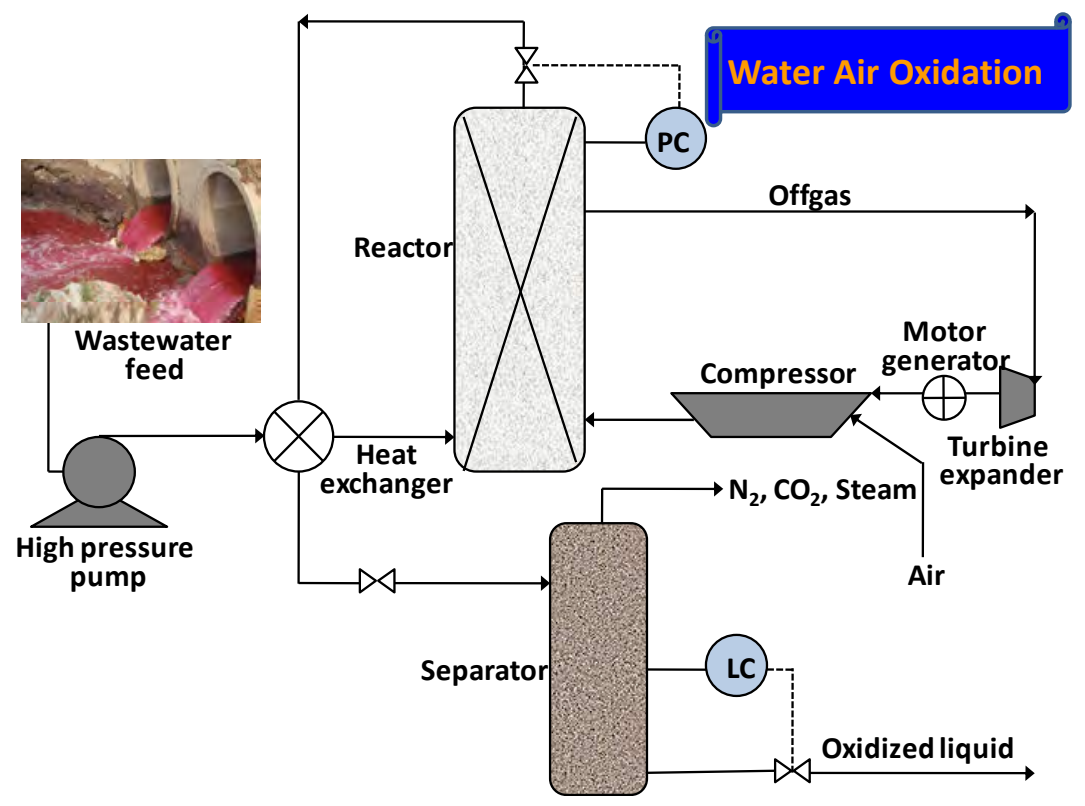

Fig. 2. Basic wet air oxidation plant flow sheet. 
operating temperature. The treated effluent can be used to preheat fresh wastewater [14]. Liquid and non-condensable gases are separated in a separator. The off-gases can be expanded in a turbine to recover energy. The gasses are then treated using carbon absorption beds or afterburners to reduce the concentration of organic matters. The oxidized liquid phase can be directly disposed of or, most often, subjected to biological treatment.

WAO requires much less fuel than any other thermal oxidation process such as incineration. This is because the only energy required for WAO is that used to make up the difference in enthalpy between the incoming and outgoing streams. The capital cost of a WAO system is higher, and the reactor itself can account for a significant fraction (50\%) of the total equipment cost. The capital investment can be reduced if one selects a WAO system based on $\mathrm{O}_{2}$ instead of air. Prasad et al. [15] studied the technological and economic aspects of both air- and $\mathrm{O}_{2}$-based systems and concluded that $\mathrm{O}_{2}$-based WAO systems gave higher profitability. The operating costs are almost entirely for power consumption to compress air and to pump liquids [16]. Furthermore, WAO becomes self-sustaining with no additional fuel requirement when the COD is above 20000 $\mathrm{mg} / \mathrm{L}$ [17], that is, energy recovery (thermal or mechanical) becomes possible when the feed COD is sufficiently high [18]. Costs can further be reduced by reducing the severity of the oxidation conditions by the use of suitable catalysts.

\section{Research history - first attempts}

The first patent on wet air oxidation was 102 years ago. In 1911, Strehlenert applied for a patent for the treatment of sulfite liquor (from pulp production) by oxidation with compressed air at $180^{\circ} \mathrm{C}$ [13]. In 1927, Hanglin and Stauf [19] purified a solution containing metallic salts and organic impurities using wet air oxidation. The temperature was above $130^{\circ} \mathrm{C}$, and the pressure was above $0.2 \mathrm{MPa}$. The WAO technology was firmly established and developed by Zimmermann [7-10]. The first known WAO plant was set up in 1958 in Norway for the treatment of sulfite liquors, but this was later closed down due to uneconomical operation.

A truly successful application of the WAO technique as a commercial process for wastewater treatment came in the early 1960s with its application for the recovery of pulping chemicals from waste liquors and the complete oxidation of sewage sludge. The Zimpro Corporation built several WAO plants for the oxidation of sewage sludge. On the basis of the work with sewage sludge, new applications for WAO were discovered, such as the conditioning of sludge for easy dewatering and improving settling characteristics. Commercial applications for hazardous wastes were started in the early 1970s. Up to 1995 more than 200 full scale WAO plants were in operation for the treatment of a wide variety of effluent streams [13]. The major application of WAO is still for the treatment of sewage sludge, with more than $50 \%$ of the WAO plants built being used for this purpose [20].

\section{Research hotspots}

Although WAO can quickly and completely treat high concentration and highly toxic pollutants, its operational conditions and equipment requirements are severe. Capital and operating costs are high compared to other treatments, such as biological treatments. Therefore, the wide application of WAO has restrictions.

During the past two decades, the application of catalysts for the catalytic WAO (CWAO) process has been a research hotspot. CWAO not only reduces the severity of the reaction conditions but also more easily decomposes even refractory pollutants, thereby reducing capital and operational cost [13,21-31]. Regardless of the wastewater type, the operating cost of CWAO is about half that of non-catalytic WAO due to milder operating conditions and shorter residence time [32]. According to the type of catalyst, CWAO can be divided into homogeneous CWAO processes and heterogeneous CWAO processes.

Homogeneous copper salts are the most active catalysts in the homogeneous CWAO process [13,33-35]. As there is no additional third phase, mass transfer and reaction in a homogeneous CWAO process are therefore similar to the non-catalytic system. Reactor operation is also simpler compared to the heterogeneous CWAO process [25]. The main disadvantage of the homogeneous CWAO process is that an additional separation step is required to remove or recover the metal ions (homogeneous catalyst) from the treated effluent due to their toxicity, which increases operational cost [12]. Several heterogeneous CWAO processes have been developed in the last two decades, including the Ciba-Geigy process, LOPROX (low pressure wet oxidation) process, and WPO (wet peroxide oxidation) process [28].

In recent years, heterogeneous CWAO has received much attention because a separation step is not necessary. Many solid catalysts including noble metals, metal oxides, and mixed oxides have been widely studied for the CWAO process [12]. However, in addition to being cost-effective, the solid catalyst must also show satisfactory stability and durability under the severe operating conditions and acidic environments in WAO systems. Catalyst deactivation can occur due to leaching, sintering, poisoning of active sites or fouling of the catalyst surface by deposition of organic or inorganic compounds [25]. To overcome these problems, several solid catalysts based on supported precious metals were studied [36-43]. Supported precious metal catalysts not only are less prone to deactivation by the leaching of the active phase, but they also have higher overall activity for the oxidation of various pollutants. Several commercial heterogeneous CWAO processes have been developed, such as the NS-LC (Nippon Shokubai liquid chromatography) process, Osaka Gas process, and Kurita Process [28].

\section{Application in dye wastewater}

Synthetic dyes are widely used in many industries such as the textile, cosmetic, printing, pharmacy, and food processing industries [44]. These dyes, which exist in large volumes of wastewater generated by the factories, threaten human health by their toxicity and potential carcinogenicity [45]. The removal of these dyes in the wastewater has attracted much interest 
and is an important practical problem [46]. There were many studies for dye removal with WAO in the past two decades. According to the treated agents, these studies can be divided into those on pure compounds (important model pollutants) and wastewater containing toxic and hazardous compounds. From their findings, a better understanding of the reactions taking place during WAO (reaction mechanism and kinetics) was obtained, which is important as it leads to the reliable design of oxidation reactors and also to cost reduction by optimization of the operating conditions.

\subsection{Model pollutants}

Studies on the WAO of model dyes are listed in Table 2. Lin et al. [47] studied the WAO of a prepared direct dye solution using a CoAIPO $4-5$ catalyst. The results showed that $\mathrm{CoAIPO}_{4}-5$ effectively improved the rate of color removal, and the activation energy of the color removal reaction was decreased from 110 to $75 \mathrm{~kJ} / \mathrm{mol}$ as the catalyst loading was increased from 0 to $3.0 \mathrm{~g} / \mathrm{L}$. In their subsequent work [48], the performance of CoAlPO $4-5$ and $\mathrm{CeO}_{2}$ as catalysts in the WAO process was stud- ied. By adsorption and oxidation, $\mathrm{CoAlPO}_{4}-5$ effectively decreased the American Dye Manufacturers Institute color and COD values in the dye solution. At a reaction temperature of $135{ }^{\circ} \mathrm{C}$ and a pressure of $1.0 \mathrm{MPa}$, color and COD removal after $2 \mathrm{~h}$ reached $95 \%$ and $90 \%$, respectively.

Zhu et al. [49] used four types of powder catalysts whose main active components were $\mathrm{Cu}, \mathrm{Ce}, \mathrm{Cd}$, and $\mathrm{Co}-\mathrm{Bi}$ in the CWAO treatment of a $\mathrm{H}$-acid solution. The comparison of the efficiency of the different catalysts showed that the Ce3Cu1 (3:1) catalyst was the best. At the conditions of $200^{\circ} \mathrm{C}, 3 \mathrm{MPa}$ of $\mathrm{O}_{2}$ partial pressure, $\mathrm{pH}=12$, and $30 \mathrm{~min}$ of reaction time, the COD removal rate was over $90 \%$.

To get further insight into the dominant reaction pathway of the catalytic and non-catalytic WAO processes, Arslan-Alaton et al. [50] added isopropyl alcohol and bromide as $\bullet \mathrm{OH}$ scavengers into the reaction solution. The catalytic processes were appreciably less sensitive to the presence of $\bullet \mathrm{OH}$ scavengers than non-catalyzed WAO, implying that CWAO did not mainly use a free radical type reaction mechanism. The results supported the free radical chain mechanism only for non-catalyzed WAO [50].

Table 2

Summary of WAO studies with model dyes.

\begin{tabular}{|c|c|c|c|c|c|c|}
\hline Year & Dye & Reactor & Catalyst & Conditions & Effect & Ref. \\
\hline 2001 & Direct dye & Autoclave & $\mathrm{CoAIPO}_{4}-5$ & $\begin{array}{l}135 \text { or } 145^{\circ} \mathrm{C}, \\
1 \mathrm{MPa} \mathrm{O}_{2}\end{array}$ & $\begin{array}{l}\text { Activation energy of color removal } \\
75 \mathrm{~kJ} / \mathrm{mol}\end{array}$ & {$[47]$} \\
\hline 2002 & H-acid & Autoclave & $\mathrm{Ce} 3 \mathrm{Cu} 1$ & $\begin{array}{l}135 \text { or } 145^{\circ} \mathrm{C} \\
1 \mathrm{MPa} \mathrm{O}_{2}\end{array}$ & Removal of $90 \%$ COD in $30 \mathrm{~min}$ & [49] \\
\hline 2002 & Acid dye Orange II & Stainless steel unions & $\begin{array}{l}\text { Non-catalytic; } \\
\mathrm{H}_{4} \mathrm{SiW}_{12} \mathrm{O}_{40} \text { and } \\
\mathrm{Na}_{2} \mathrm{HPW}_{12} \mathrm{O}_{40}\end{array}$ & $\begin{array}{l}160-290{ }^{\circ} \mathrm{C} \\
0.6-3.0 \mathrm{MPa} \mathrm{O}\end{array}$ & $\begin{array}{l}\text { Arrhenius parameters } E_{\mathrm{a}}=84 \\
\mathrm{~kJ} / \mathrm{mol} \text { and } A=5.6 \times 10^{7} / \mathrm{min}\end{array}$ & {$[50]$} \\
\hline 2003 & Reactive dye & Autoclave & $\mathrm{CoAlPO}_{4}-5 \& \mathrm{CeO}_{2}$ & $\begin{array}{l}135^{\circ} \mathrm{C}, 1.0 \mathrm{MPa} \\
\mathrm{O}_{2}\end{array}$ & $\begin{array}{l}\text { Color and COD removal were } 95 \% \\
\text { and } 90 \% \text {, respectively, after } 2 \mathrm{~h}\end{array}$ & $0[48]$ \\
\hline 2004 & Phenol & $\begin{array}{l}\text { Trickle bed } \\
\text { reactor }\end{array}$ & Active Pt and Ru & $\begin{array}{l}393 \text { and } 473 \mathrm{~K}, \\
5 \text { and } 8 \mathrm{MPa} \mathrm{O}_{2}\end{array}$ & $\begin{array}{l}\text { 58-107 kJ/mol of activation } \\
\text { energy }\end{array}$ & [51] \\
\hline 2005 & Azo dyes & $\begin{array}{l}\text { Stainless-steel } \\
\text { high-pressure reactor }\end{array}$ & Pt/MWNT & $\begin{array}{l}150{ }^{\circ} \mathrm{C}, 6.9 \mathrm{MPa} \\
\mathrm{O}_{2}\end{array}$ & $\begin{array}{l}\text { Almost } 100 \% \text { removal of dyes in } \\
2 \mathrm{~h}\end{array}$ & [52] \\
\hline 2007 & Methyl orange & Glass reactor & $\mathrm{Fe}_{2} \mathrm{O}_{3}-\mathrm{CeO}_{2}-\mathrm{TiO}_{2} / \gamma-\mathrm{Al}_{2} \mathrm{O}_{3}$ & $\begin{array}{l}25^{\circ} \mathrm{C} \text {, } \\
\text { atm. pressure air }\end{array}$ & $\begin{array}{l}\text { Removal of } 98.09 \% \text { color and } \\
96.08 \% \text { TOC in } 2.5 \mathrm{~h}\end{array}$ & [53] \\
\hline 2007 & Cationic red X-GRL & Autoclave & Non-catalytic & $\begin{array}{l}60-180^{\circ} \mathrm{C} \\
0-1.2 \mathrm{MPa} \mathrm{O}\end{array}$ & $\begin{array}{l}\text { Removal of } 92 \% \text { dye at } 180^{\circ} \mathrm{C} \text { in } \\
1 \mathrm{~h}\end{array}$ & [54] \\
\hline 2009 & Safranin-T & Three-neck glass flask & $\mathrm{Zn}_{1.5} \mathrm{PMo}_{12} \mathrm{O}_{40}$ nanotube & $\begin{array}{l}25^{\circ} \mathrm{C} \text {, } \\
\text { atm. pressure air }\end{array}$ & $\begin{array}{l}\text { Removal of } 98 \% \text { color and } 95 \% \\
\text { COD within } 40 \mathrm{~min}\end{array}$ & {$[55]$} \\
\hline 2011 & Basic Yellow 11 & $\begin{array}{l}\text { Stainless-steel } \\
\text { high-pressure reactor }\end{array}$ & $\begin{array}{l}\mathrm{Ni} \text { - and Fe-doped mixed } \\
\text { oxides }\end{array}$ & $120^{\circ} \mathrm{C}, 5 \mathrm{MPa} \mathrm{O}_{2}$ & $\begin{array}{l}\text { High TOC and toxicity removal } \\
\text { efficiency }\end{array}$ & [56] \\
\hline 2011 & CI Basic Yellow 11 & Autoclave & Pt nanotube & $\begin{array}{l}120-180^{\circ} \mathrm{C} \\
5 \mathrm{MPa} \mathrm{O}_{2}\end{array}$ & $\begin{array}{l}\text { Effective to destroy the dye } \\
\text { structure }\end{array}$ & [57] \\
\hline 2011 & $\begin{array}{l}\text { Basic Yellow 11, Crystal violet, } \\
\text { Naphtol Blue Black }\end{array}$ & Autoclave & $\begin{array}{l}\text { Ni catalysts supported } \\
\text { on hydrotalcites }\end{array}$ & $120^{\circ} \mathrm{C}, 5 \mathrm{MPa} \mathrm{O}_{2}$ & Removal of $95 \%$ dye & [58] \\
\hline 2012 & Crystal violet & Autoclave & $\mathrm{Hi} / \mathrm{HT}$ & $220^{\circ} \mathrm{C}, 5 \mathrm{MPa} \mathrm{O}$ & $11.15 \mathrm{~kJ} / \mathrm{mol}$ of activation energy & [59] \\
\hline 2012 & Cationic red GTL & Glass reactor & Mo-Zn-Al-O catalyst & $\begin{array}{l}25^{\circ} \mathrm{C} \text {, } \\
\text { atm. pressure air }\end{array}$ & $\begin{array}{l}\text { Removal of } 80.1 \% \text { color and } 50.9 \% \\
\text { TOC }\end{array}$ & $0[60]$ \\
\hline 2012 & Crystal violet & Trickle-bed reactor & $\mathrm{Ni} / \mathrm{MgAlO}$ & $\begin{array}{l}120-180{ }^{\circ} \mathrm{C} \\
2.5-6 \mathrm{MPa} \mathrm{O}\end{array}$ & Removal of $64 \%$ TOC in $350 \mathrm{~h}$ & [61] \\
\hline 2012 & Crystal violet & Autoclave & $\mathrm{Ni} / \mathrm{MgAlO}$ & $\begin{array}{l}140-200^{\circ} \mathrm{C} \\
5 \mathrm{MPa} \mathrm{O}_{2}\end{array}$ & Removal of $98 \%$ dye & [62] \\
\hline 2013 & Azo dyes & Autoclave & $\mathrm{CuO} / \gamma-\mathrm{Al}_{2} \mathrm{O}_{3}$ & $\begin{array}{l}80^{\circ} \mathrm{C}, \\
\text { atm. pressure } \mathrm{O}_{2}\end{array}$ & $\begin{array}{l}\text { Removal of } 99 \% \text { color and } 70 \% \text { of } \\
\text { TOC in } 2 \mathrm{~h}\end{array}$ & [63] \\
\hline 2013 & Chromotrope 2R & Trickle-bed reactor & $\mathrm{Ni} / \mathrm{MgAlO}$ & $\begin{array}{l}100-180^{\circ} \mathrm{C} \\
2.5 \mathrm{MPa} \text { air }\end{array}$ & Conversion of $82 \%$ TOC at $150^{\circ} \mathrm{C}$ & [64] \\
\hline 2013 & Basic Yellow 11 & Autoclave & $\mathrm{Ni} / \mathrm{MgAlO}$ & $\begin{array}{l}100-200{ }^{\circ} \mathrm{C} \\
3-6 \mathrm{MPa} \mathrm{O} \mathrm{O}_{2}\end{array}$ & $\begin{array}{l}\text { Improvement of } 49.1 \% \text { for the } \\
\text { CWAO process }\end{array}$ & [65] \\
\hline
\end{tabular}


Cybulski et al. [51] developed active Pt and Ru catalysts for the CWAO of phenol solution. A kinetic analysis of phenol conversion and COD changes was given based on a lumped reaction network. Most of the activation energy obtained ranged from 58 to $107 \mathrm{~kJ} / \mathrm{mol}$. The reaction orders for phenol ranged from 0.94 to 2.0 and those for $\mathrm{O}_{2}$ from 0.22 to 0.85 . They later use supported Pt catalysts to treat wastewater from a fine chemicals plant and also obtained good results [66].

Garcia and co-workers [52] have done much work on the CWAO of model dyes. They first used multi-walled carbon nanotubes (MWNT) to prepare supported Pt catalysts and applied them in the CWAO of azo dye solutions [52,57,67]. The CWAO of a textile wastewater was also performed using the same catalyst. Complete color removal and 51.2\% TOC abatement were obtained. Later, they used Ni catalysts supported on hydrotalcites [58] and mixed oxides [56,59,61,62,64,65], and especially for the Ni catalyst supported on $\mathrm{Mg}$-Al mixed oxides (Ni/MgAlO), much work was done to apply it in different reactors $[61,64]$ and with different dyes $[64,65]$.

In order to develop a catalyst with high activity and stability for the CWAO process at room temperature and atmospheric pressure, Liu et al. [53] prepared $\mathrm{Fe}_{2} \mathrm{O}_{3}-\mathrm{CeO}_{2}-\mathrm{TiO}_{2} / \gamma-\mathrm{Al}_{2} \mathrm{O}_{3}$ by sequential impregnation. The degradation of an azo dye (methyl orange) in the CWAO process with this catalyst at room temperature and atmospheric pressure was investigated, and it was shown that the catalyst had excellent catalytic activity in treating synthetic wastewater containing $500 \mathrm{mg} / \mathrm{L}$ methyl orange. The $98.09 \%$ of the color and $96.08 \%$ of TOC were removed in $2.5 \mathrm{~h}$. In their recent work [60], a new Mo-Zn-Al-O catalyst was developed for the CWAO of cationic red GTL at room temperature and atmospheric pressure. The optimal conditions of the $\mathrm{pH}$ value, initial concentration of dye, and catalyst dosage were $4.0,85 \mathrm{mg} / \mathrm{L}$, and $2.72 \mathrm{~g} / \mathrm{L}$, respectively, for the maximum decolorization of $80.1 \%$ and TOC removal of $50.9 \%$. Zhang et al. [55] have also developed a catalyst with high activity and stability for the CWAO of pollutant dyes at room condition. Using the new polyoxometalate $\mathrm{Zn}_{1.5} \mathrm{PMo}_{12} \mathrm{O}_{40}$ with a nanotube structure as the catalyst, the CWAO of Safra$\operatorname{nin}-\mathrm{T}(10 \mathrm{mg} / \mathrm{L})$, a hazardous textile dye, using air at room temperature and atmospheric pressure, the removal of $98 \%$ color and 95\% COD within 40 min was achieve. Hua et al. [63] also prepared a catalyst $\left(\mathrm{CuO} / \gamma^{-}-\mathrm{Al}_{2} \mathrm{O}_{3}\right)$ that was used under atmospheric pressure. At $80{ }^{\circ} \mathrm{C}$, almost $99 \%$ of color and $70 \%$ of TOC of azo dye solution were removed in $2 \mathrm{~h}$.

\subsection{Wastewater studies}

Studies on the WAO of wastewater are summarized in Table 3. Lin and Ho [68] treated desizing wastewater, a typical high strength industrial wastewater, with WAO. The desizing wastewater sample was obtained from a large textile dyeing and finishing plant. They found that over 60\% COD removal efficiency was easily obtained in $1 \mathrm{~h}$. Also, it was observed that WAO can increase the biodegradability of the treated desizing wastewater, thus rendering it suitable for subsequent activated sludge treatment. In their subsequent work [69], catalysts $\left(\mathrm{CuSO}_{4}\right.$ and $\left.\mathrm{Cu}\left(\mathrm{NO}_{3}\right)_{2}\right)$ were introduced into the WAO process. The COD removal percentage was increased from $60 \%$ to $80 \%$ by $1 \mathrm{~h}$ treatment. Kinetic studies indicated that the generalized kinetic model yielded a better fit to the kinetic data than the two stage, first order model [70].

Lei et al. [74] studied the treatment of dyeing and printing wastewater from the textile industry by WAO. They found that an alumina-supported catalyst had an advantage over other metal salt catalysts in that it can be easily separated from the treated wastewater by filtration and recycled. The reaction was carried out in a $2 \mathrm{~L}$ high pressure reactor. In another work, by a homogeneous catalyst screening experiment, they found that of all catalysts tested, copper salts were the most effective. Anions in the salt solutions were active in the catalytic process. Nitrate ions were more effective than sulfate ions. A mixture of salts containing different metals performed better than a single salt [71]. They introduced a modified first order kinetics model to study the WAO of printing and dye wastewater [72]. The model simulations were in good agreement with experimental data. The results indicated that the ratio of degraded organic matter was independent of temperature and can be improved by using a catalyst. In their subsequent work, their focus changed from

Table 3

Summary of studies on dye wastewater WAO.

\begin{tabular}{|c|c|c|c|c|c|}
\hline Year & Wastewater & Reactor & Catalyst & Conditions & Effect \\
\hline 1996 & Desizing wastewater & $\begin{array}{l}\text { High pressure } \\
\text { Parr reactor }\end{array}$ & $\mathrm{CuSO}_{4}$ and $\mathrm{Cu}\left(\mathrm{NO}_{3}\right)_{2}$ & $150-250^{\circ} \mathrm{C}, 7 \mathrm{MPa}$ air & $80 \%$ COD removal in $1 \mathrm{~h} \mathrm{[69]}$ \\
\hline 1997 & Desizing wastewater & $\begin{array}{l}\text { High pressure } \\
\text { Parr reactor }\end{array}$ & $\mathrm{CuSO}_{4}$ and $\mathrm{Cu}\left(\mathrm{NO}_{3}\right)_{2}$ & $175-260{ }^{\circ} \mathrm{C}, 4-8 \mathrm{MPa}$ air & $70 \%$ COD removal in $1 \mathrm{~h}$ [70] \\
\hline 2000 & Textile wastewater & Autoclave & $\begin{array}{l}\mathrm{CuSO}_{4}, \mathrm{FeSO}_{4}, \mathrm{Fe}_{2}\left(\mathrm{SO}_{4}\right)_{3}, \mathrm{MnSO}_{4}, \\
\mathrm{Cu}\left(\mathrm{NO}_{3}\right)_{2}, \mathrm{Fe}\left(\mathrm{NO}_{3}\right)_{3}, \mathrm{Mn}\left(\mathrm{NO}_{3}\right)_{2}\end{array}$ & $240^{\circ} \mathrm{C}, 1.5 \mathrm{MPa} \mathrm{O}_{2}$ & $\begin{array}{l}61 \%-77 \% \text { COD removal [71] } \\
\text { in } 30 \mathrm{~min}\end{array}$ \\
\hline 2001 & Textile wastewater & Autoclave & $\mathrm{CuO}$ and $\mathrm{Cu}\left(\mathrm{NO}_{3}\right)_{2}$ & $150-300{ }^{\circ} \mathrm{C}, 2.65 \mathrm{MPa} \mathrm{O} 2$ & $\begin{array}{l}\text { 1st order rate constant: } \\
0.0492-0.0559 / \mathrm{min}\end{array}$ \\
\hline 2003 & Textile wastewater & $\begin{array}{l}\text { Autoclave } \\
\text { batch reactor }\end{array}$ & Non-catalytic & $423-563 \mathrm{~K}, 1.69 \mathrm{MPa} \mathrm{O}_{2}$ & $\begin{array}{l}\text { activation energy: } \\
37.5 \mathrm{~kJ} /(\mathrm{mol} \cdot \mathrm{K})\end{array}$ \\
\hline 2005 & Textile wastewater & $\begin{array}{l}\text { Stainless-steel } \\
\text { high pressure reactor }\end{array}$ & Pt/MWNT & $150^{\circ} \mathrm{C}, 6.9 \mathrm{MPa} \mathrm{O}_{2}$ & $51.2 \%$ TOC abatement \\
\hline 2006 & $\begin{array}{l}\text { Chemical plant } \\
\text { wastewater }\end{array}$ & Fixed-bed reactor & CBC-supported Pt & $393-473 \mathrm{~K}, 5.0 \mathrm{MPa} \mathrm{O}_{2}$ & High COD removal rates [66] \\
\hline 2011 & Ink-plant wastewater & Autoclave & Pt nanotube & $120-180{ }^{\circ} \mathrm{C}, 5 \mathrm{MPa} \mathrm{O}_{2}$ & $\begin{array}{l}\text { Effective to remove TOC [57] } \\
\text { and toxicity }\end{array}$ \\
\hline 2011 & Textile wastewater & Autoclave & Ni catalysts (supp. Hydrotalcites) & $120^{\circ} \mathrm{C}, 5 \mathrm{MPa} \mathrm{O}{ }_{2}$ & Effective to remove TOC [58] \\
\hline
\end{tabular}


the use of industrial wastewater to simulated wastewater to study the degradation mechanism in the WAO of dyes [54].

Chen and coworkers [73] designed a WAO system to carry out a COD kinetic study of the treatment of printing and dye wastewater from the textile industry. A simple first order kinetic model described the removal of WAO-removable COD well. The activation energy was $37.5 \mathrm{~kJ} / \mathrm{mol}$.

\section{Conclusions}

Studies on the WOA of dye wastewater began from the middle 1990s. The early studies focused on the treatment of wastewater. In the last decade, research focus changed to model dye studies. Most WOA studies are on CWOA, especially heterogeneous catalytic WOA. The use of a solid catalyst not only improved treatment efficiency but also reduced the severity of the reaction conditions, e.g., a Mo-Zn-Al-O catalyst can be active under room conditions. Many present studies are fundamental research focusing on the development of new catalysts for the WAO process. Process technology and modeling techniques should also be developed to optimize the process and solve problems in the practical application of WAO for the treatment of dye wastewater.

\section{References}

[1] Wu H F, Wang S H. J Hazard Mater, 2012, 243: 86

[2] Wu H F, Wang S H, Kong H L, Liu T T, Xia M F. Bioresour Technol, 2007, 98: 1501

[3] Bautista P, Mohedano A F, Casas J A, Zazo J A, Rodriguez J J. J Chem Technol Biotechnol, 2008, 83: 1323

[4] Lee J C, Kim M S, Kim C K, Chung C H, Cho S M, Han G Y, Yoon K J, Kim B W. Korean J Chem Eng, 2003, 20: 862

[5] Glaze W H. Environ Sci Technol, 1987, 21: 224

[6] Vogelpohl A, Kim S M. J Ind Eng Chem, 2004, 10: 33

[7] Zimmermann F J. US Patent 2665 249. 1954

[8] Zimmermann F J. GB Patent 706 686. 1954

[9] Zimmermann F J. Chem Eng, 1958, 65(17): 117

[10] Zimmermann F J. In: Proceedings of the 13th International Waste
Conference. Purdue, 1958. 409

[11] Hancock F E. Catal Today, 1999, 53: 3

[12] Kim K H, Ihm S K. J Hazard Mater, 2011, 186: 16

[13] Mishra V S, Mahajani V V, Joshi J B. Ind Eng Chem Res, 1995, $34: 2$

[14] Pradt L A. Chem Eng Progr, 1972, 68(12): 72

[15] Prasad J, Materi G E. In: Proceedings of the 7th National Conference of Hazardous Wastes and Hazardous Materials. Silver Spring, 1990. 372

[16] Wilhelmi A R, Knopp P V. Chem Eng Progr, 1979, 75(8): 46

[17] Joshi J B, Shah Y T, Parulekar S J. Indian Chem Eng, 1985, 37(2): 3

[18] Chou C L, Verhoff F H. Ind Eng Chem Proc Des Dev, 1981, 20: 12

[19] Hanglin F, Stauf F W I G. DE Patent 500 813. 1927

[20] Dietrich M J, Randall T L, Canney P J. Environ Progr, 1985, 4: 171

[21] Bhargava S K, Tardio J, Prasad J, Föger K, Akolekar D B, Grocott S C. Ind Eng Chem Res, 2006, 45: 1221

[22] Cybulski A. Ind Eng Chem Res, 2007, 46: 4007

[23] Debellefontaine H, Foussard J N. Waste Manage, 2000, 20: 15

[24] Imamura S. Ind Eng Chem Res, 1999, 38: 1743

[25] Kolaczkowski S T, Plucinski P, Beltran F J, Rivas F J, McLurgh D B. Chem Eng J, 1999, 73: 143

[26] Larachi F. Top Catal, 2005, 33: 109

[27] Levec J, Pintar A. Catal Today, 2007, 124: 172

[28] Luck F. Catal Today, 1996, 27: 195

[29] Mantzavinos D, Sahibzada M, Livingston A G, Metcalfe I S, Hellgardt K. Catal Today, 1999, 53: 93

[30] Matatov-Meytal Y I, Sheintuch M. Ind Eng Chem Res, 1998, 37: 309

[31] Oliviero L, Barbier J Jr, Duprez D. Appl Catal B, 2003, 40: 163

[32] Levec J. Chem Biochem Eng, 1997, 11: 47

[33] Chang C J, Lin J C, Chen C K. J Chem Technol Biotechnol, 1993, 57: 355

[34] Chang C J, Li S S, Ko C M. J Chem Technol Biotechnol, 1995, 64: 245

[35] Shende R V, Mahajani V V. Ind Eng Chem Res, 1994, 33: 3125

[36] Zhang Q L, Chuang K T. Appl Catal B, 1998, 17: 321

[37] Barbier J Jr, Delanoe F, Jabouille F, Duprez D, Blanchard G, Isnard P. J Catal, 1998, 177: 378

[38] Imamura S, Fukuda I, Ishida S. Ind Eng Chem Res, 1988, 27: 718

[39] Imamura S, Doi A, Ishida S. Ind Eng Chem Prod Res Dev, 1985, 24 : 75

[40] Imamura S, Hirano A, Kawabata N. Ind Eng Chem Prod Res Dev, 1982, 21: 570

[41] Ito M M, Akita K, Inoue H. Ind Eng Chem Res, 1989, 28: 894

\section{Graphical Abstract}

Chin. J. Catal., 2014, 35: 1-7 doi: 10.1016/S1872-2067(12)60724-4

\section{Wet air oxidation for the decolorization of dye wastewater: An overview of the last two decades}

Jie Fu, George Z. Kyzas*

Auburn University, USA;

Technological Educational Institute of Kavala, Greece;

Aristotle University of Thessaloniki, Greece

Wet air oxidation (WAO) is one of the most economically and technologically viable advanced oxidation processes for dye wastewater. The wide studies on WAO of dye wastewater began from 1995. Recent studies focused on real wastewaters.

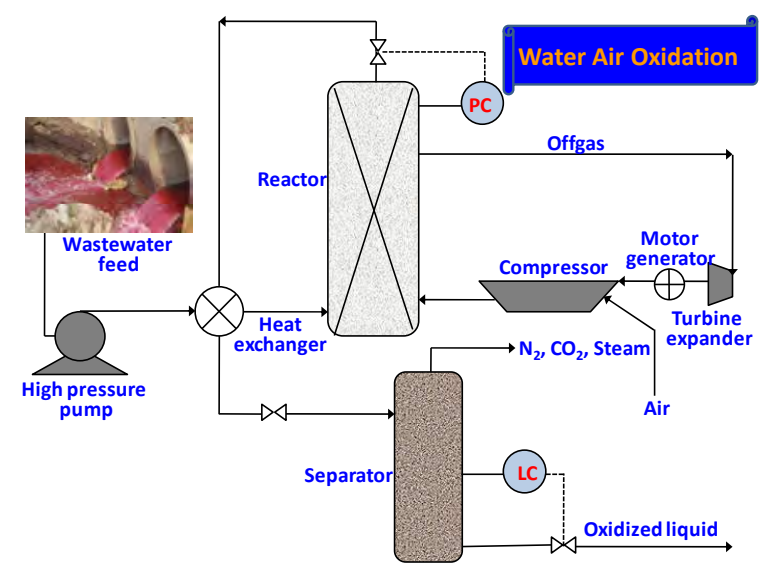


[42] Pintar A, Levec J. Chem Eng Sci, 1992, 47: 2395

[43] Sadana A, Katzer J R. Ind Eng Chem Fundam, 1974, 13: 127

[44] Fu J, Xu Z, Li Q S, Chen S, An S Q, Zeng Q F, Zhu H L. J Environ Sci, 2010, 22: 512

[45] Zeng Q F, Fu J, Shi Y T, Zhu H L. Ozone Sci Eng, 2009, 31: 37

[46] Fu J, Ding Y H, Ma G Y, Yang J, Zeng Q F, Liu M Y, Xia D S, Zhu H L, An S Q. Ozone Sci Eng, 2009, 31: 294

[47] Lin S S, Chang D J, Chen M T, Chen C C.J Environ Sci Health A, 2001, 36: 2055

[48] Chang D J, Chen I P, Chen M T, Lin S S. Chemosphere, 2003, 52: 943

[49] Zhu W P, Bin Y J, Li Z H, Jiang Z P, Yin T. Water Res, 2002, 36: 1947

[50] Arslan-Alaton I, Ferry J L. Dyes Pigm, 2002, 54: 25

[51] Cybulski A, Trawczynski J. Appl Catal B, 2004, 47: 1

[52] Garcia J, Gomes H T, Serp P, Kalck P, Figueiredo J L, Faria J L. Catal Today, 2005, 102-103: 101

[53] Liu Y, Sun D Z. Appl Catal B, 2007, 72: 205

[54] Lei L C, Dai Q Z, Zhou M H, Zhang X W. Chemosphere, 2007, 68: 1135

[55] Zhang Y, Li D L, Chen Y, Wang X H, Wang S T. Appl Catal B, 2009, 86: 182

[56] Ovejero G, Rodriguez A, Vallet A, Gomez P, Garcia J. Water Sci Technol, 2011, 63: 2381

[57] Ovejero G, Rodriguez A, Vallet A, Garcia J. Color Technol, 2011, 127: 10

[58] Ovejero G, Sotelo J L, Rodriguez A, Vallet A, Garcia J. Environ Sci
Pollut Res, 2011, 18: 1518

[59] Ovejero G, Rodriguez A, Vallet A, Willerich S, Garcia J. Appl Catal B, 2012, 111-112: 586

[60] Xu Y, Li X Y, Cheng X, Sun D Z, Wang X Y. Environ Sci Technol, 2012, 46: 2856

[61] Ovejero G, Rodriguez A, Vallet A, Garcia J. Appl Catal B, 2012, 125: 166

[62] Ovejero G, Rodriguez A, Vallet A, Garcia J. Ind Eng Chem Res, 2012, 51: 11367

[63] Hua L, Ma H R, Zhang L. Chemosphere, 2013, 90: 143

[64] Vallet A, Ovejero G, Rodriguez A, Peres J A, Garcia J. J Hazard Mater, 2013, 244-245: 46

[65] Ovejero G, Rodriguez A, Vallet A, Garcia J. Chem Eng J, 2013, 215-216: 168

[66] Cybulski A, Trawczynski J. Water Environ Res, 2006, 78: 12

[67] Rodríguez A, García J, Ovejero G, Mestanza M. Water Sci Technol, 2009, 60: 1989

[68] Lin S H, Ho S J. J Environ Sci Health A, 1996, 31: 355

[69] Lin S H, Ho S J. Appl Catal B, 1996, 9: 133

[70] Lin S H, Ho S J. J Environ Eng-ASCE, 1997, 123: 852

[71] Lei L C, Chen G H, Hu X J, Yue P L. Water Environ Res, 2000, 72: 147

[72] Hu X J, Lei L C, Chen G H, Yue P L. Water Res, 2001, 35: 2078

[73] Chen G H, Lei L C, Hu X J, Yue P L. Sep Purif Technol, 2003, 31: 71

[74] Lei L, Hu X, Chu H P, Chen G, Yue P L. Water Sci Technol, 1997, 35: 311 